\title{
Documents from the Magisterium
}

AG Ad gentes divinitus: The Decree on the Mission Activity of the Church (Vatican II, December 7, 1965)

APR Aperite portas Redemptori: Bull: Open the Doors to the Redeemer for the Jubilee Year Commemorating the 1950th Year of Redemption (John Paul II, January 6, 1983)

CA Centesimus annus: Encyclical Letter on the rooth Anniversary of Rerum novarum (John Paul II, May I, I99I)

CCC Catechism of the Catholic Church, Librería Editrice Vaticana (John Paul II, October II, 1992)

CL Christifideles laici: Post-synodal Apostolic Exhortation on the Vocation and the Mission of the Lay Faithful (John Paul II, December 30, 1988)

DP Puebla Document: Conclusions of the Third General Conference of the Latin American Episcopate (March 23, 1979)

EDE Ecclesia de Eucharistia: Encyclical Letter on the Eucharist and Its Relationship to the Church (John Paul II, April I7, 2003)

EIA Ecclesia in America: Post-synodal Apostolic Exhortation on the Church in America (John Paul II, January 22, 1999)

EG Evangelii gaudium: Apostolic Exhortation on the Joy of the Gospel (Francis, November 24, 2013)

EN Evangelii nuntiandi: Apostolic Exhortation on Evangelization in the Modern World (Paul VI, December 8, 1975)

FR Fides et ratio: Encyclical Letter on Faith and Reason (John Paul II, September 14, 1998)

GS Gaudium et spes: Pastoral Constitution on the Church in the Modern World (Second Vatican Council, December 7, 1965)

LE Laborem exercens: Encyclical Letter on Human Work on the Ninetieth Anniversary of Rerum novarum (John Paul II, September 14, 198I) 
NMA Navega mar adentro [Go Into Deeper Waters], Pastoral Guidelines for the New Evangelization, Update (Argentine Episcopal Conference, May 3I, 2003).

NMI Novo millennio ineunte: Apostolic Letter at the Close of the Great Jubilee of the Year 2000 (John Paul II, January 6, 200I)

RM Redemptoris missio: Encyclical Letter on the Permanent Validity of the Church's Missionary Mandate (John Paul II,

December 7, 1990)

RMA Redemptoris mater: Encyclical Letter on the Blessed Virgin Mary in the Life of the Pilgrim Church (John Paul II, March 25, 1987)

SRS Sollicitudo rei socialis: Encyclical Letter on the Social Concern of the Church on the Twentieth Anniversary of Populorum progresio (December 30, 1987).

TMA Tertio millennio adveniente: Apostolic Letter on Preparation for the Jubilee of the Year 2000 (John Paul II, November IO, 1994)

VS Veritatis splendor: Encyclical Letter on the Splendor of Truth (John Paul II, August 6, 1993) 
In Your Eyes I See My Words 
